\title{
Home Medical Equipment is Highly Being Adopted in U.S. - Explore Why?
}

\author{
Ashish Gujrathi \\ Allied Market Research, Viman Nagar Pune Sainik Nagar, Somnath Nagar, Wadgaon Sheri, Pune, Maharashtra, India.
}

Corresponding Author: Ashish Gujrathi, Allied Market Research, Viman Nagar Pune Sainik Nagar, Somnath Nagar, Wadgaon Sheri, Pune, Maharashtra, India.

Received date: December 09, 2021; Accepted date: December 27, 2021; Published date: January 07, 2022

Citation: Ashish Gujrathi, (2022). Home Medical Equipment is Highly Being Adopted in U.S. - Explore Why? J Clinical Research and Reports, 10(2); DOI:10.31579/2690-1919/221

Copyright: (C) 2022 Ashish Gujrathi. This is an open access article distributed under the Creative Commons Attribution License, which permits unrestricted use, distribution, and reproduction in any medium, provided the original work is properly cited.

\begin{abstract}
The modern technological advancements and facilities have made people welcome medical equipment to home. Most common home medical equipment include glucometer, automated external defibrillators, blood glucose monitors, blood pressure monitors, halter monitors, mobility devices, weighing scale and so on. These equipment can provide safe, convenient, cost-effective, and suitable treatments to patients at home.

Keywords: home medical equipment; modern technological advancements and facilities; provides convenient and costeffective; CAGR; US
\end{abstract}

\section{Introduction}

The modern technological advancements and facilities have made people welcome medical equipment to home. Most common home medical equipment include glucometer, automated external defibrillators, blood glucose monitors, blood pressure monitors, halter monitors, mobility devices, weighing scale and so on. These equipment can provide safe, convenient, cost-effective, and suitable treatments to patients at home.

Patients suffering from asthma and chronic diseases, such as hypertension, diabetes, respiratory diseases, cardiac disorders, blood pressure, and others have a high requirement for home medical equipment as they face difficulty in moving from one place to another. Glucometer has become a must have equipment for patients who need insulin to maintain their sugar level. Similarly, for elderly people and disable people, mobility devices such as crutches, wheelchairs, knee chairs etc. have become an essential requirement. This way, home medical devices that are certified by regulatory agencies find wide acceptance based on cost factor, safety, and convenience.

\section{Current market scenario of U.S. medical equipment: -}

According to a report published by Allied Market Research, the global U.S. home medical equipment market size is projected to reach $\$ 20,412$ million with a considerable CAGR from 2020 to 2027. Certain key factors like surge in geriatric population in U.S, high disposable income, awareness among individuals for availability of home medical care and continuous advancements in medical technology such as durable medical equipment with medical beds, stair lifts, and lift chairs are boosting the market growth to a great extent.
Moreover, the emergence of the COVID-19 pandemic has boosted the growth of the market even more. Medical equipment such as oxygen delivery devices, continuous positive airway pressure equipment, ventilators, oxygen concentrators, blood pressure monitors and blood glucose monitors have witnessed huge demand during the pandemic. This is due to rise in applications for home care settings to assist patients with mobility and to monitor progression of patient's recovery.

Recently, FDA has announced to reshape the U.S. at home testing landscape based on ACON laboratories. A rapid surge in new infections through Delta variant has made retail pharmacies to minimize the number of walk in tests for customers. So, in order to increase the availability of walk in, at home tests over the next several weeks, FDA is expecting to double the testing capacity in the U.S. For this, the company is planning to scale manufacturing of the home test.

On $6^{\text {th }}$ Oct, 2021, the White House announced one billion dollar investment in home medical equipment for COVID testes which is expected to help quadruple their availability by end of 2021. More than one hundred million rapid tests will be available to Americans each month. President announced that he is planning to use Defense Production Act to expand the production of testing kits and is going to work with Amazon, Walmart and other global retailers in order to maximize their availability.

At the same time, healthcare providers and insurers worldwide are ready to make use of fast evolving telehealth technology by adapting home medical devices and monitoring tools to treat and care patients. Owing to lower costs and more flexibility from the U.S. Centers for Medical Services, all the healthcare providers, hospitals, and doctors are highly 
leading medical device manufacturer, named Smiths Medical, has collaborated with Medline Industries for distributing Portex acapella positive expiratory pressure therapy equipment within home care settings.

- AbbVie Inc. invested more than three hundred million dollar for a gene therapy that targets choric eye conditions.

- $\quad$ Rockville, Md based biotech Regenxbio Inc. is going to invest nearly one billion dollar in milestone payments from the U.S. pharmaceutical giant. This will offer one time gene therapy for the treatment of wet age related macular degeneration, chronic retinal diseases, diabetic retinopathy, and others.

- Astra Zeneca PLC is also eligible to make an investment of nearly two hundred million dollar in Vax Equity \& milestone payments to develop twenty is more therapies.

On the other hand, few partnerships and collaborations among key market players are augmenting the growth of the market in more than one way. Electro Med Inc. has entered into an agreement with two distributors, one regional and another national, for home medical devices. Similarly, a

Furthermore, patients with mobility issues highly rely on home medical equipment facilities to get advanced treatments at home. As home medical equipment save time \& money and make it easier for patients to carry their regular activities easily at home, there is a huge demand for home medical equipment in U.S., which in turn, is supplementing the growth of the market to a huge extent. With this drift on board, the U.S. home medical equipment market is anticipated to gather remunerative prospects and exponential growth in the near future.

Author's Bio - Suchita Gupta is an explorer, musician and content writer. While pursuing MBA, she found that nothing satisfies her more than writing on miscellaneous domains. She is a writer by day, and a reader by night. Besides, she can be found entertaining her audience on social media platforms. Find her on LinkedIn \& Instagram.

This work is licensed under Creative Commons Attribution 4.0 License

To Submit Your Article Click Here: Submit Manuscript

DOI: $10.31579 / 2690-1919 / 221$
Ready to submit your research? Choose Auctores and benefit from:

$>$ fast, convenient online submission

$>$ rigorous peer review by experienced research in your field

$>$ rapid publication on acceptance

$>$ authors retain copyrights

$>$ unique DOI for all articles

$>$ immediate, unrestricted online access

At Auctores, research is always in progress.

Learn more auctoresonline.org/journals/journal-of-clinical-research-andreports 